\title{
KAJIAN LITERATUR AKTIVITAS ANTIKANKER TANAMAN BUNGA MATAHARI (HELIANTHUS ANNUS L) TERHADAP BERBAGAI KULTUR SEL KANKER
}

\author{
Ana Maria Ulfa ${ }^{1)^{*}}$, Wiwin Herd wiani ${ }^{1)}$, Ika Purwidyaningrum ${ }^{1)}$ \\ ${ }^{1}$ Fakultas Farmasi Universitas Setia Budi, Surakarta \\ Jln. Letjen Sutoyo-Mojosongo Surakarta-57127 Telp. 0271-852578 \\ Email: anaulfa0610@gmail.com
}

\begin{abstract}
Cancer is a very complex disease and ranks first in the world. The plant parts that have been studied are stems, leaves, flowers and seeds. This literature review aims to determine the cytotoxic activity of cancer cell cultures, the content of active compounds that play a role and the mechanism of action.

This literature review uses the narrative review method with collecting data of the sources and libraries with several trusted journals and sites. The journals obtained were 20 journals.

The known results can be concluded from various cancer cell cultures in the form of A549 cells, Caco -2, RD, B lymphocytes, Raji, A375, MDA-AMB 231, HCT 116, T98G, Hela and Neuroblastoma. The active compounds involved are flavonoids, palimitic acid, linolenic acid, stearidonic acid, terpenoids, sesquiterpenes and steroids, terpinene, terpinolene and linalool alkaloids, glycosides. The mechanism of action in this plant is inhibiting apoptosis, proliferation, transformation, metastasis, cell viability, influencing the apoptotic pathway to the cell cycle in the G1 phase, S phase, and G2/M phase.d

Key word: Sunflower plant, cell culture, compound, mechanism.
\end{abstract}

\begin{abstract}
ABSTRAK
Penyakit kanker merupakan penyakit yang sangat kompleks dan menduduki peringkat pertama di dunia. Bagian tanaman yang sudah diteliti yaitu batang, daun, bunga dan biji. Kajian literatur ini bertujuan untuk mengetahui aktivitas sitotoksik terhadap kultur sel kanker, kandungan senyawa aktif yang berperan dan mekanisme aksi.

Kajian literatur menggunakan metode naratif review dengan mengumpulkan data dari berbagai sumber dan pustaka dengan beberapa jurnal dan artikel ilmiah. Jurnal yang diperoleh sebanyak 20 jurnal.

Hasil yang diketahui dapat disimpulkan dari berbagai kultur sel kanker berupa Sel A549, Caco -2, RD, limfosit B, Raji, A375, MDA -AMB 231, HCT 116, T98G, Hela dan Neuroblastoma. Kandungan senyawa aktif yang berperan berupa Flavonid, asam palimitat, asam linolenat, asam Stearidonic, Terpenoid, sesquiterpen dan steroid, terpinene, terpinolene dan linalool alkaloid, glikosida. Mekanisme aksi pada tanaman ini menghambat apoptosis, proliferasi, transformasi, metastasis, viabilitas sel, mempengaruhi jalur apoptosis terhadap siklus sel pada fase G1, fase S, dan fase G2 / M.

Kata kunci : Tanaman bunga matahari, kultur sel, senyawa, mekanisme
\end{abstract}

\section{PENDAHULUAN}

Penyakit kanker adalah adanya kelainan yang abnormal di dalam tubuh yang sebelumnya protoonkogen menjadi onkogen dan di dunia menjadi peringkat pertama. Penyakit kanker yang meningkat dipengaruhi oleh kebiasaan buruk sehari - hari yang kita lakukan seperti menghirup asap rokok, jarang olah raga, tidak suka mengkonsumsi buah, makan makanan yang cepat saji dan kurang beserat, memasak makanan dengan suhu tinggi sehingga berubah senyawanya menjadi akrilamid. (Haryanti \& Widyastuti, 2017).

Penyakit kanker merupakan penyebab kematian yang utama di dunia sebesar 7,6 juta di tahun 2016 kemungkinan besar 13\% akan meningkat pada prakiraan tahun 2030 sebesar 13,1 juta (WHO, 2016). Indonesia menempati urutan peringkat ke 7 setara dengan $(5,7 \%)$ setelah penyakit komorbid yang lain seperti 
diabetes, Tbc, darah tinggi (hipertensi), stroke (Kemenkes, 2014).

Faktor risiko yang berperan dalam penyakit ini yaitu kelebihan berat badan, tidak suka makan dengan kandungan serat yang tinggi, aktivitas tubuh yang kurang, mengkonsumsi rokok dan alkohol berlebih. Keterbatasan dalam pengobatan kemoterapi yaitu efek samping obat, kejadian resistensi, dan efek utama yang belum memungkinkan. Kemoterapi dilakukan dengan tujuan untuk menghambat sel kanker, menekan perumbuhan sel protoonkogen menjadi onkogen sehingga mengurangi terjadinya proses pembentukan sel kanker (karsinogenesis) (Kemenkes, 2015)

Tanaman bunga matahari adalah tanaman yang berasal dari daerah Amerika, tanaman ini mempunyai nama botani yaitu Heliantus annus L termasuk keluarga Asteraceae, ketinggiannya bisa mencapai 1-3 meter berdasarkan species dan genus. Bentuk tubuh tanaman memiliki kulit yang tebal dan kokoh arah tumbuhnya mengikuti sinar matahari (Novela, 2017). Beberapa penelitian melaporkan tanaman ini memiliki aktivitas farmakologi seperti antioksidan, antikanker, anti-inflamasi, antihipertensi, pelindung kulit, hipokolesterolemia, analgesik, dan aktivitas antibakteri, antidiabetik dan efek menenangkan pada saraf, otot, dan pembuluh darah. Ini juga digunakan dalam masalah konstipasi, disentri, dan kemih (Shuangshuang, 2017).

Kandungan kimia dalam tanaman ini terdiri dari alkaloid, terpenoid, flavonoid, steroid, tanin dan saponin. Berdasarkan uraian di atas, maka penulis ingin mengkaji tentang efek farmakologi anti kanker pada tanaman bunga maahari (Helianthus annus L) dengan metode kajian literatur dengan harapan bisa menambah data base baru dan sumber pengetahuan informasi untuk peneliti selanjutnya, selain itu untuk menambah wawasan ilmu pengetahuan mengenai tanaman bunga matahari untuk dijadikan pengembangan dan penemuan suatu obat dalam penelitian.

Penelitian ini akan dipaparkan dari beberapa hasil penelitian yang terkait tentang aktivitas antikanker, kriteria yang diikuti untuk pemilihan data dalam tinjauan ini berupa aktivitas sitotoksik secara in vitro pada tanaman bunga matahari bagian ekstrak dan senyawa hasil isolat dari tanaman ini yang mempunyai efek sitotoksik, selain itu mekanisme antikanker yang meliputi antiproliferasi, apoptosis dan pada kultur sel kanker.

\section{METODE PENELITIAN}

Metode dalam penelitian ini adalah penelitian dengan menggunakan metode studi pustaka atau kajian literatur. Kajian literatur merupakan penelitan dengan cara mengumpulkan data dengan tema tertentu yang diperoleh dari berbagai sumber seperti penelitian, buku, website resmi dan pustaka lain.

Kriteria inklusi pada penelitian ini yaitu jurnal ilmiah terpublikasi dengan waktu yang tak terbatas yang berisi tentang potensi antikanker pada tanaman Helianthus annus L. Sedangkan kriteria eksklusi dalam penelitian ini yaitu jurnal ilmiah baik nasional atau internasional yang diterbitkan dibawah tahun 2010 yang pembahasannya tidak mengarah terhadap aktivitas antikanker pada tanaman Helianthus annus $\mathrm{L}$.

\section{JALANNYA PENELITIAN}

\section{Tahapan penentuan rumusan masalah}

Rumusan masalah merupakan salah satu tahapan yang sangat penting dalam kegiatan penelitian. Pada tahap ini, seorang peneliti mempersempit masalah penelitian dengan menyediakan dua atau lebih pertanyaan penelitian yang hendak ditemukan dalam penelitian Rumusan masalah ini berfungsi sebagai panduan untuk merencanakan jawaban yang hendak ditemukan dalam penelitian, dengan demikian rumusan masalah dapat dijadikan pedoman, penentu arah atau fokus dari sebuah penelitian.

\section{Kajian literatur}

Tahapan dalam kajian literatur merupakan langkah penting dalam penelitian. Langkah ini antara lain identifikasi senyawa aktif, species tanaman bunga matahari, metode ekstraksi, pelarut dan mekanis me aksi yang berisi informasi yang berhubungan dengan permasalahn penelitian secara sistematis. Data ini meliputi jurnal, abstrak, dan data ilmiah yang relevan. Tujuan utama dari literatur ini adalah untuk melihat apa saja penelitian yang sudah pernah dilakukan dengan masalah yang akan diteliti.

\section{Penelusuran jurnal}

Berdasarkan hasil penelusuran jurnal dengan situs seperti google scholar, serta 
beberapa data base jurnal seperti, Portalgaruda, Pubmed, Science direct.

Peneliti menemukan 73 jurnal sesuai dengan kata kunci, selanjutnya peneliti melakukan skrining jurnal sebanyak 40 jurnal kemudian jurnal yang diskrining sesuai dengan kriteria inklusi dan eksklusi sehingga jurnal yang didapatkan sebanyak 20 jurnal full text yang dilakukan untuk kajian literatur.



\section{Gambar 1. Diagram alir kajian literatur jurnal}

\section{Pengumpulan data}

Data adalah sekumpulan informasi yang diperlukan untuk pengambilan keputusan. Data ini perlu disusun dan disimpan dengan menggunakan metode tertentu, pada umumnya data diberi nama sesuai dengan informasi yang tercangkup didalamnya. Penelusuran pustaka pada artikel yang dipublikasi peneliti melakukan pencarian jurnal penelitian yang telah dipublikasikan diinternet mengunakan situs seperti google scholar, serta beberapa data base jurnal seperti, Portalgaruda, Pubmed, Science direct.

Kata kunci yang tepat dengan mengunakan: uji aktivitas sitotosik tanaman bunga matahari dan mekanisme antikanker. Jurnal yang sesuai dengan kriteria inklusi dan ekslusi pada penelitian selanjutnya diambil dan dianalisis.

Kajian literatur pada penelitian ini menggunakan jurnal ilmiah dengan jangka waktu kurang dari 10 tahun yaitu antara 2010 - 2020 yang bisa diakses secara fulltext. Jenis jurnal yang akan dikaji adalah jurnal dengan penelitian berbahasa Indonesia dan inggris dengan subjek tamanan bunga matahari Helianthus annus L, penelitian literatur artikel dengan tema potensi obat antikanker pada tanaman bunga matahari. Penelitian ini peneliti menggunakan data sekunder. Penelitian ini peneliti menggunakan data sekunder, dalam penelitian data sekunder peneliti mengumpulkan sebuah jurnal atau artikel ilmiah yang berisi antara lain:

Tabel 1. Tahapan pengumpulan data berdasarkan aktivitas

\begin{tabular}{ccccccccc}
\hline No & $\begin{array}{c}\text { Tanaman } \\
\text { bunga } \\
\text { matahari }\end{array}$ & $\begin{array}{c}\text { Bagian } \\
\text { tanaman }\end{array}$ & $\begin{array}{c}\text { Metode } \\
\text { ekstraksi }\end{array}$ & $\begin{array}{c}\text { Pelarut } \\
\text { yang } \\
\text { digunakan }\end{array}$ & $\begin{array}{c}\text { Metode uji } \\
\text { sitotoksik }\end{array}$ & $\begin{array}{c}\text { Kultur } \\
\text { sel }\end{array}$ & $\begin{array}{c}\text { Hasil/nilai } \\
\left(\text { IC }_{50}\right)\end{array}$ & Pustaka \\
\hline
\end{tabular}

Tabel 2. Tahapan pengumpulan data berdasarkan senyawa aktif

No Bagian tanaman Senyawa aktif Metode ekstraksi Metode uji Pustaka

Tabel 3. Tahapan pengumpulan data berdasarkan mekanisme aksi

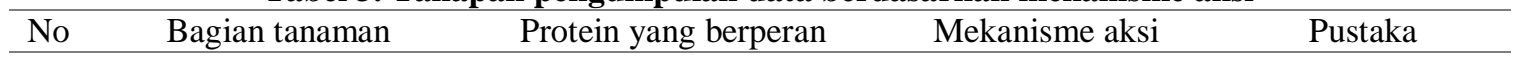

\section{Sintesis Data}

Penelitian kajian lieratur ini dianalisis dengan menggunakan metode naratif review dengan mengelompokkan data hasil ekstraksi yang sejenis sesuai dengan hasil yang diukur untuk menjawab tujuan, artikel penelitian yang sudah sesuai dengan kriteria inklusi kemudian dikumpulkan dan dibuat ringkasan meliputi nama peneliti, tahun terbit jurnal, negara penelitian, judul penelitian, metode penelitian, dan hasil ringkasan. Ringkasan dalam jurnal dibuat tabel dan diurutkan berdasarkan alphabet sesuai dengan jurnal.

Analisis full text jurnal setidaknya harus dibaca dengan teliti dan dicermati. Ringkasan jurnal harus memuat analisis terhadap isi yang terdapat dalam tujuan penelitian dan hasil temuan penelitian. Analisis penelitian ini 
menggunakan analisis isi jurnal, kemudian dilakukan ringkasan terhadap isi jurnal yang akan direview, data yang sudah dikumpulkan selanjutnya dicari persamaan dan perbedaannya lalu dilakukan pembahasan untuk menarik kesimpulan.

\section{HASIL DAN PEMBAHASAN}

Hasil penelitian kajian literatur ini berdasarkan 73 jurnal yang memiliki potensi yang relevan yang diseleksi untuk kelayakan dari 73 jurnal tersebut, 40 jurnal berasal dari beberapa data base jurnal elektronik (e - journal) dengan situs seperti google scholar, serta beberapa data base jurnal seperti, Portalgaruda, Pubmed, Science direct.

Setelah pemilihan judul dan abstrak sebanyak 53 jurnal dikeluarkan, karena tidak memenuhi kriteria inklusi, selanjutnya 20 jurnal yang diidentifikasi memenuhi kriteria inklusi kemudian 20 jurnal yang diidentifikasi memenuhi kriteria digunakan sebagai data primer untuk penyusunan review penelitian. Kata kunci yang tepat dengan mengunakan: sitotosik, tanaman bunga matahari dan mekanisme antikanker. Kajian literatur ini dilakukan untuk dengan tujuan untuk mengetahui tanaman bunga matahari (Helianthus annus $\mathrm{L}$ ) memiliki aktivitas sitotoksik terhadap berbagai kultur sel kanker, kemudian untuk mengetahui kandungan senyawa aktif yang diduga memiliki aktivitas antikanker, dan mekanisme aksi senyawa aktif pada tanaman bunga matahari, dengan tehnik pengumpulan data kemudian diambil dengan cara mengumpulkan data (data collection) kemudian dianalisis mengunakan metode naratif review. Artikel dan jurnal yang memenuhi kriteria inklusi dan eksklusi diambil kemudian dianalisis, jurnal yang digunakan berbahasa indonesia dan inggris. Kajian literatur ini menggunakan terbitan tahun yang berbeda diakses dalam bentuk full text.

Kultur sel kanker yang diperoleh dalam penelitian ini berupa Sel A549 (sel kanker paru), Sel Caco -2 (sel kanker kolorektal, Sel (RD) Rhabddomysarcoma (Sel kanker otot rangka), Sel limfosit B ( Sel Raji), Sel A375 sel (melanoma) Sel MDA -AMB 231, sel HCT 116 ( sel kolorectal)Sel T98G (sel otak dan sumsum tulang belakang), Sel HCT 116 (sel kanker kolon) Sel Hela (kanker servic) dan sel neuroblastoma. Kajian literatur ini disajikan dalam bentuk tabel yang mengarah pada aktivitas kultur sel kanker, kandungan senyawa aktif yang berperan dan mekanisme aksi pada aktivitas sel kanker yang memodulasi ekspresi protein yang diteliti secara in vitro 
Hasil Penelitian Kajian Literatur Berdasarkan Nilai Inhibition Concentration (IC (50)

Tabel 4. Hasil Penelitian Kajian Literatur Berdasarkan Nilai Inhibition Concentration ( IC $_{50}$ )

\begin{tabular}{|c|c|c|c|c|c|c|c|c|c|c|c|}
\hline No & Senyawa aktif & $\begin{array}{l}\text { Bagian } \\
\text { tanaman }\end{array}$ & $\begin{array}{c}\text { Metode } \\
\text { pemisahan }\end{array}$ & $\begin{array}{l}\text { Metode } \\
\text { isolasi }\end{array}$ & $\begin{array}{c}\text { Pelarut } \\
\text { yang } \\
\text { digunkan }\end{array}$ & $\begin{array}{l}\text { Media yang } \\
\text { digunakan }\end{array}$ & $\begin{array}{l}\text { Metode uji } \\
\text { sitotoksik }\end{array}$ & Kultur sel & Hasil/nilai (IC & $\begin{array}{l}\text { Kontrol positif/ } \\
\text { kontrol media }\end{array}$ & Pustaka \\
\hline 1 & $\begin{array}{l}\text { 5- } \\
\text { pentildihidrofuran- } \\
\text { 2(3H)-satu, (Z)- } \\
\text { metil 4- } \\
\text { (isobutiriloksi) but- } \\
\text { 3-enoat, dan asam } \\
\text { 2-fenilasetat }\end{array}$ & $\begin{array}{l}\text { Daun } \\
\text { (Isolat) }\end{array}$ & - & $\begin{array}{l}\text { Spektrometr } \\
\text { i massa dan } \\
\text { kromatograf } \\
\text { i gas (GC- } \\
\text { MS) }\end{array}$ & $\begin{array}{l}\text { n-Hexan } \\
\text { dan etil } \\
\text { asetat }\end{array}$ & $\begin{array}{l}\text { Roswell Park } \\
\text { Memorial } \\
\text { Institute } \\
\text { (RPMI) }\end{array}$ & $\begin{array}{l}\text { MTT } \\
\text { Assay }\end{array}$ & $\begin{array}{l}\text { Sel A549 (sel kanker } \\
\text { paru) }\end{array}$ & $\begin{array}{l}\text { Memiliki aktivitas } \\
\text { antiproliferasi sebesar } \\
22,14 \mu \mathrm{g} / \mathrm{ml}\end{array}$ & Etoposid & $\begin{array}{l}\text { Shupaphon \& } \\
\text { predanon } \\
(2019)\end{array}$ \\
\hline 2 & Flavonid & Biji & $\begin{array}{l}\text { Sokletasi dan } \\
\text { Refluks }\end{array}$ & - & n- Hexsan & $\begin{array}{l}\text { Dulbecco's } \\
\text { Modified Eagle } \\
\text { Media } \\
\text { (DMEM) }\end{array}$ & $\begin{array}{l}\text { MTT } \\
\text { Assay }\end{array}$ & $\begin{array}{l}\text { Sel Caco -2 (sel } \\
\text { kanker kolorektal) }\end{array}$ & $\begin{array}{l}\text { Memiliki aktivitas } \\
\text { kemopreventiv } \\
\text { sebesar } 100 \mu \mathrm{g} / \mathrm{ml}\end{array}$ & $\begin{array}{l}\text { Kontrol media } \\
+ \text { sel }\end{array}$ & $\begin{array}{l}\text { Smith et al } \\
\text { (2016) }\end{array}$ \\
\hline 3 & $\begin{array}{l}\text { asam palimitat, } \\
\text { asam linolenat, } \\
\text { asam -Linoleat dan } \\
\text { asam Stearidonic }\end{array}$ & $\begin{array}{l}\text { Minyak } \\
\text { atsiri Biji } \\
\text { Bunga } \\
\text { Matahari }\end{array}$ & destilasi & - & n- Hexsan & $\begin{array}{l}\text { Roswell Park } \\
\text { Memorial } \\
\text { Institute } \\
\text { (RPMI) }\end{array}$ & $\begin{array}{l}\text { MTT } \\
\text { Assay }\end{array}$ & $\begin{array}{l}\text { Sel (RD) } \\
\text { Rhabddomysarcoma } \\
\text { (Sel kanker otot } \\
\text { rangka) }\end{array}$ & $\begin{array}{l}\text { Memiliki aktivitas } \\
\text { menghambat } \\
\text { proliferasi sel kanker } \\
\text { sebesar } 166,4 \mu \mathrm{g} / \mathrm{ml}\end{array}$ & $\begin{array}{l}\text { Kontrol media } \\
+ \text { sel }\end{array}$ & $\begin{array}{l}\text { KH-Al } \\
\text { Jumaily R et } \\
\text { al (2013) }\end{array}$ \\
\hline 4 & $\begin{array}{l}\text { terpinene, } \\
\text { terpinolene dan } \\
\text { linalool }\end{array}$ & $\begin{array}{l}\text { Minyak } \\
\text { atsiri bunga } \\
\text { matahari }\end{array}$ & Hidrodestilasi & - & $\begin{array}{l}\text { Air } \\
\text { deionisasi }\end{array}$ & $\begin{array}{l}\text { Dulbecco's } \\
\text { Modified Eagle } \\
\text { Media } \\
\text { (DMEM) }\end{array}$ & $\begin{array}{l}\text { MTT } \\
\text { Assay }\end{array}$ & $\begin{array}{l}\text { Sel A375 sel } \\
\text { (melanoma) } \\
\text { Sel MDA -AMB } \\
\text { 231, sel HCT 116 ( } \\
\text { sel kolorectal) } \\
\text { Sel T98G (sel otak } \\
\text { dan sumsum tulang } \\
\text { belakang) }\end{array}$ & $\begin{array}{l}\text { Memiliki aktivitas } \\
\text { proliferasi sel A375, } \\
\text { 9MDA- MB231, HCT } \\
116 \text { dan T98G } \\
\text { memiliki nilai } \mathrm{IC}_{50} \\
\text { masing masing } \\
\text { sebesar } 3.02 ; 3.79 ; \\
3.46 ; 12.82(\mu \mathrm{g} / \mathrm{ml} .)\end{array}$ & Cisplatin & $\begin{array}{l}\text { Orsomando } \\
\text { et al (2016) }\end{array}$ \\
\hline 5 & $\begin{array}{l}\text { alkaloid, saponin, } \\
\text { flavonoid dan tanin }\end{array}$ & $\begin{array}{l}\text { Ekstrak } \\
\text { batang }\end{array}$ & Maserasi & - & Etanol 96\% & $\begin{array}{l}\text { Roswell Park } \\
\text { Memorial } \\
\text { Institute } \\
\text { (RPMI) }\end{array}$ & $\begin{array}{l}\text { MTT } \\
\text { Assay }\end{array}$ & $\begin{array}{l}\text { Sel HCT } 116 \\
\text { (sel kanker kolon) }\end{array}$ & $\begin{array}{l}\text { Menghambat } \\
\text { aktivitas } 50 \% \\
\text { proliferasi sebesar } \\
200 \mathrm{ppm}\end{array}$ & - & $\begin{array}{l}\text { Nasruddin } \\
\text { (2013) }\end{array}$ \\
\hline 6 & $\begin{array}{l}\text { alkaloid, saponin, } \\
\text { flavonoid dan tanin }\end{array}$ & $\begin{array}{l}\text { Ekstrak } \\
\text { batang }\end{array}$ & Maserasi & - & Etanol 70\% & $\begin{array}{l}\text { Roswell Park } \\
\text { Memorial } \\
\text { Institute } \\
\text { (RPMI) }\end{array}$ & $\begin{array}{l}\text { MTT } \\
\text { Assay }\end{array}$ & $\begin{array}{l}\text { Sel HCT } 116 \\
\text { (sel kanker kolon) }\end{array}$ & $\begin{array}{l}\text { Memiliki aktivitas } \\
\text { sitotoksik sebesar } \\
\text { IC }_{50} 463.36 \text { ppm }\end{array}$ & - & $\begin{array}{l}\text { Syifa dkk } \\
(2013)\end{array}$ \\
\hline 7 & $\begin{array}{l}\text { Flavonoid, } \\
\text { sesquiterpen dan } \\
\text { lakton }\end{array}$ & $\begin{array}{l}\text { Ekstrak } \\
\text { daun }\end{array}$ & Maserasi & - & Etanol & $\begin{array}{l}\text { Roswell Park } \\
\text { Memorial } \\
\text { Institute } \\
\text { (RPMI) } \\
\end{array}$ & $\begin{array}{l}\text { MTT } \\
\text { Assay }\end{array}$ & $\begin{array}{l}\text { Sel Hela } \\
\text { (kanker servic) }\end{array}$ & $\begin{array}{l}\text { Memiliki aktivitas } \\
\text { sitotoksik sebesar } \\
\text { IC }_{50} 377,46 \mu \mathrm{g} / \mathrm{ml} \text {. }\end{array}$ & Cisplatin & $\begin{array}{l}\text { Amruloh m. } \\
\text { (2013) }\end{array}$ \\
\hline 8 & Lektin & $\begin{array}{l}\text { Isolat Biji } \\
\text { (Lektin ) }\end{array}$ & - & $\begin{array}{l}\text { Kromatogra } \\
\text { fi afinitas }\end{array}$ & - & $\begin{array}{l}\text { Dulbecco's } \\
\text { Modified Eagle } \\
\text { Media (DMEM) }\end{array}$ & $\begin{array}{l}\text { MTT } \\
\text { Assay }\end{array}$ & Neuroblastoma & $\begin{array}{l}\text { Memiliki aktivitas } \\
\text { sitotoksik sebesar } \\
\text { IC }_{50} 200 \mu \mathrm{g} / \mathrm{ml} \text {. }\end{array}$ & - & $\begin{array}{l}\text { Pinedo et al } \\
\text { (2017) }\end{array}$ \\
\hline
\end{tabular}


Penelitian tentang aktivitas sitotoksik tanaman bunga matahari (Heliantus annus L) dilakukan dalam kurun waktu tahun yang berbeda. Penelitian sitotoksik berdasarkan nilai inhibitor concntration $\left(\mathrm{IC}_{50}\right)$ pada tabel 6 penelitian terhadap kultur sel kanker paru sel A549 terdapat satu peneliti yaitu Shupaphon \& predanon (2019) penelitian penghambatan aktivitas sitotoksik antikanker sel kanker paru dari bagian tanamannya adalah daun (Heliantthus annus L) dengan pelarut non polar n-Heksan dan etil asetat adalah sebesar $\mathrm{IC}_{50}$ $22,14 \mu \mathrm{g} / \mathrm{ml}$. Metode pemisahan zat aktif dilakukan dengan menggunakan Spektrometri massa dan kromatografi gas (GC-MS). Senyawa yang didapatkan dari hasil isolasi yaitu 5pentildihidrofuran-2(3H)-satu, (Z)-metil 4(isobutiriloksi)but-3-enoat, dan asam 2fenilasetat. Pelarut non polar adalah pelarut yang tidak polar biasanya digunakan untuk mengekstraksi senyawa yang sukar larut dalam pelarut polar/senyawa non polar seperti halnya isolat -isolat yang didapatkan. Metode uji yang digunakan untuk menentukan viabilitas sel yaitu MTT Assay dengan kontrol positif berupa etoposid. Media yang digunakan dalam uji in vitro adalah roswell park memorial intitute (RPMI).

Penelitian kultur sel kanker kolorektal (sel Caco2) dilakukan oleh tiga peneliti yaitu Smith et al 2016, uji aktivitas agen kemopreventif pada kultur sel kanker kolorektal dari biji tanaman Helianthus annus L dengan pelarut non polar n- heksan adalah sebesar $\mathrm{IC}_{50} 100 \mu \mathrm{g} / \mathrm{ml}$. Metode pemisahan zat aktif dilakukan dengan menggunakan sokletasi dan reflluks. Senyawa yang didapatkan dari hasil ekstraksi yaitu flavonoid dan fenolik. Metode uji yang digunakan untuk menentukan viabilitas sel yaitu MTT Assay. Media yang digunakan dalam uji in vitro adalah Dulbecco's Modified Eagle Media (DMEM). Nasruddin 2013, penghambatan aktivitas proliferasi terhadap kultur sel HCT 116 (sel kanker kolon) dari batang Helianthus annus L dengan pelarut non polar etanol $96 \%$ adalah sebesar $50 \%$ pada ekstrak air dengan nilai inbibitor concentration $\mathrm{IC}_{50}$ sebesar 200ppm. Metode pemisahan zat aktif dilakukan dengan menggunakan maserasi. Senyawa yang didapatkan dari hasil maserasi alkaloid, saponin, flavonoid dan tanin . Metode uji yang digunakan untuk menentukan viabilitas sel yaitu MTT Assay. Media yang digunakan dalam uji in vitro adalah roswell park memorial intitute (RPMI). Syifa dkk 2013, aktivitas penghambatan proliferasi terhadap kultur sel HCT 116 (sel kanker kolon) dari batang Helianthus annus L dengan pelarut non polar etanol $70 \%$ adalah sebesar IC $_{50} 463.36$ ppm. Metode pemisahan zat aktif dilakukan dengan menggunakan maserasi. Senyawa yang didapatkan dari hasil maserasi alkaloid, saponin, flavonoid dan tanin. Metode uji yang digunakan untuk menentukan viabilitas sel yaitu MTT Assay. Media yang digunakan dalam uji in vitro adalah roswell park memorial intitute (RPMI) Berdasarkan data tersebut dapat disimpulkan bahwa aktivitas sitotoksik ekstrak etanol $70 \%$ mendekati konsentrasi moderat aktif sebagai antikanker.

Penelitian terhadap kultur sel kanker otot rangka (sel RD) dilakukan oleh satu peneliti yaitu Jumaily 2013, aktivitas proliferasi pada kultur sel (RD) Rhabddomysarcoma (Sel kanker otot rangka) dari minyak atsiri pada tanaman Helianthus annus L dengan pelarut non polar nheksan adalah sebesar $\mathrm{IC}_{50} 166,4 \mu \mathrm{g} / \mathrm{ml}$. Metode pemisahan zat aktif dilakukan dengan menggunakan destilasi. Senyawa yang didapatkan dari hasil destilasi yaitu asam palimitat, asam linolenat, asam -Linoleat dan asam Stearidonic. Metode uji yang digunakan untuk menentukan viabilitas sel yaitu MTT Assay. Media yang digunakan dalam uji in vitro adalah roswell park memorial intitute (RPMI).

Penelitian terhadap kultur sel melanoma (sel A375) kultur sel kanker MDA -AMB 231), kultur sel kanker kolorektal (sel HCT 116) kultur sel kanker Sel T98G sel otak dan sumsum tulang belakang dilakukan oleh satu peneliti yaitu Orsomando et al 2016, uji aktivitas penghambatan proliferasi terhadap kultur sel A375 sel (melanoma) Sel MDA -AMB 231, sel HCT 116 (sel kolorectal) Sel T98G (sel otak dan sumsum tulang belakang) dari bunga pada tanaman Helianthus annus L dengan pelarut air deionisasi adalah sebesar $\mathrm{IC}_{50} 3.02 ; 3.79 ; 3.46$; $12.82(\mu \mathrm{g} / \mathrm{ml})$. Metode pemisahan zat aktif dilakukan dengan menggunakan hidrodestilasi. Senyawa yang didapatkan dari hasil 
hidrodestilasi terpinene, terpinolene linalool. Metode uji yang digunakan untuk menentukan viabilitas sel yaitu MTT Assay dengan kontrol positif berupa cisplatin. Media yang digunakan dalam uji in vitro adalah Dulbecco's Modified Eagle Media (DMEM).

Penelitian berdasarkan kultur sel kanker serviks (sel Hela) dilakukan oleh satu peneliti yaitu amrulloh 2013, uji penghambatan aktivitas proliferasi terhadap kultur kanker serviks hela dari daun Helianthus annus L dengan pelarut non polar etanol $96 \%$ adalah sebesar IC $_{50} 377,46$ $\mu \mathrm{g} / \mathrm{ml}$. Metode pemisahan zat aktif dilakukan dengan menggunakan maserasi. Senyawa yang didapatkan dari hasil maserasi flavonoid, sesquiterpen lakton. Metode uji yang digunakan untuk menentukan viabilitas sel yaitu MTT Assay. Media yang digunakan dalam uji in vitro adalah roswell park memorial intitute (RPMI).

Penelitian terhadap kultur sel kanker neuroblastoma dilakukan oleh satu peneliti yaitu pinedo et al 2017, Uji penghambatan aktivitas proliferasi terhadap kultur sel kanker neuroblastoma dari isolat biji Helianthus annus $\mathrm{L}$ adalah sebesar $\mathrm{IC}_{50}$ sebesar $200 \mu \mathrm{g} / \mathrm{ml}$. Metode pemisahan zat aktif dilakukan dengan menggunakan kromatografi afinitas. Senyawa yang didapatkan dari hasil kromatografi afinitas Lectin. Lectin adalah protein bioaktif dengan potensi dalam pengobatan kanker. Metode uji yang digunakan untuk menentukan viabilitas sel yaitu MTT Assay Media yang digunakan dalam uji in vitro adalah Dulbecco's Modified Eagle Media (DMEM).

Penelitian terhadap kandungan senyawa aktif yang diduga memiliki aktivitas antikanker pada tanaman bunga matahari Helianthus annus L. Pengobatan secara alami untuk mengurangi resistensi pengunaan obat golongan kemoterapi untuk agen botani dan biologis baru tanaman bunga matahari memiliki aktivitas sitotoksik pada kultur sel kanker, adapun kandungan senyawa yang terdapat pada tanaman yang berperan pada aktivitas sitotoksik dan mekanisme aksi kultur sel kanker diperoleh data data sebagai berikut senyawa 5-
pentildihidrofuran-2(3H)-satu, (Z)-metil 4(isobutiriloksi) but-3-enoat, dan asam 2fenilasetat (Shupaphon \& predanon 2019). Flavonid (Smith et al 2016). Asam palimitat, asam linolenat, asam -Linoleat dan asam Stearidonic, (KH-Al Jumaily $\mathrm{R}$ et al 2013). Terpenoid, sesquiterpen dan steroid, (AlShukaili \& Hossain 2019). Terpinene , terpinolene dan linalool, (Orsomando et al 2016). Alkaloid, glikosida, flavonid dan terpenoid, (Islam et al 2016). Alkaloid, saponin, flavonoid dan tanin, (Nasruddin 2013). Steroid dan sesquiterpen (Hafidloh 2014). Alkaloid, saponin, flavonoid dan tanin (Syifa dkk 2013). Flavonoid, sesquiterpen dan lakton (Amruloh M 2013). Lektin (Pinedo et al 2017).

Tanaman bunga matahari terbukti efektifitasnya yang berperan sebagai antikanker aktivitas kandungan senyawanya antara lain senyawa sesquiterpen mengeblok pada jalur persinyalan G2 padakultur sel kanker serviks, flavonoid memblok degradasi dari protein p53 dari okogen E6 hasil dari proses ini berupa apoptosis. Kandungan senyawa 5pentildihidrofuran-2(3H)-satu, (Z)-metil 4(isobutiriloksi) but-3-enoat, dan asam 2fenilasetat menghambat pada alfaglukosidase, untuk asam palimitat, asam linolenat, asam Linoleat dan asam Stearidonic menghambat sel tumor padat dan meningkatkan jumlah sel kelenjar getah bening dan mengurangi proliferasi pada sel kanker pada senyawa terpenoid berperan sebagai apoptosis sel kanker secara terprogram dan menghambat proses proliferasi pada kultur sel kanker. Saponin berperan sebagai penghambatan viabilitas pada kultur sel kanker. Tanin menghambat pertumbuhan pada kultur sel kankerdan Alkaloid mempengaruhi proses proliferasi dan induksi apoptosis.

Berdasarkan kumpulan dari penelitian yang sudah disebutkan bahwa bagian tanaman yang paling banyak dilakukan penelitian yaitu bagian biji tanaman. Nilai sitotoksik yang berperan aktif terdapat pada bagian tanaman yaitu isolat daun dengan nlai IC50 sebesar 22,14 $\mu \mathrm{g}$ pada penelitian shupaphon \& predanon 2019. 
Hasil Penelitian Kajian Literatur Berdasarkan Mekanisme Kerja

Tabel 5. Hasil Penelitian Kajian Literatur Berdasarkan Mekanisme Kerja

\begin{tabular}{|c|c|c|c|c|}
\hline No & Senyawa & $\begin{array}{c}\text { Protein yang } \\
\text { berperan }\end{array}$ & Mekanisme aksi & Pustaka \\
\hline 1. & Seskuiterpenoid & BCL 2 dan Bax & $\begin{array}{l}\text { Menginduksi apotosis dengan meningkatkan level } \\
\text { ekspresi protein Bax, dan menghambat protein Bcl-2 }\end{array}$ & $\begin{array}{l}\text { Basu \& } \\
\text { Maier } \\
(2018)\end{array}$ \\
\hline 2. & $\begin{array}{l}\text { Seskuiterpenoid } \\
\text { lacton }\end{array}$ & Caspase 3 & $\begin{array}{l}\text { Menginduksi apoptosis dan menghambat proliferasi sel } \\
\text { melalui penghambatan NF kB. }\end{array}$ & $\begin{array}{l}\text { Siriwan et } \\
\text { al (2011) }\end{array}$ \\
\hline 3. & Seskuiterpen lakton & Caspase 3 & Menginduksi proses apoptosis dan penghambatan NF- KB & $\begin{array}{l}\text { Basio et al } \\
(2015)\end{array}$ \\
\hline 4. & $\begin{array}{l}\text { Fenolik dan } \\
\text { flavonoid }\end{array}$ & Caspase 3 dan cox 2 & $\begin{array}{l}\text { menginduksi proses apoptosis dengan peningkatan } \\
\text { aktivitas caspase } 3 \text {, dan anti inflamasi pada aktivitas cox } 2\end{array}$ & $\begin{array}{l}\text { Smith et al } \\
\text { (2016) }\end{array}$ \\
\hline 5. & Flavonid & - & $\begin{array}{l}\text { Menghambat proliferasi sel dan tranformasi sel } \\
\text { karsinogenik, senyawa flavonoid mampu menginduksi } \\
\text { apoptosis sel PC-3 ( Prostate cancer) }\end{array}$ & $\begin{array}{l}\text { Xu R et al } \\
(2013)\end{array}$ \\
\hline 6. & $\begin{array}{l}\text { Flavon dan } \\
\text { Flavanon }\end{array}$ & $\begin{array}{l}\text { cAmp protein kinase } \\
\text { dan inhibitor } \\
\text { fosfodiesterase }\end{array}$ & $\begin{array}{l}\text { Mempengaruhi proliferasi seluler dan viabilitas pada sel } \\
\text { HT29 ( cancer colon) }\end{array}$ & $\begin{array}{l}\text { Agulloa et } \\
\text { al (1996) }\end{array}$ \\
\hline 7. & $\begin{array}{l}\text { Terpenoid } \\
\text { dehydrothyrsiferol }\end{array}$ & - & $\begin{array}{l}\text { Mempengaruhi jalur apoptosis terhadap siklus sel pada } \\
\text { fase } \mathrm{G} 1 \text {, fase } \mathrm{S} \text {, dan fase } \mathrm{G} 2 \text { / M }\end{array}$ & $\begin{array}{l}\text { Pec M et } \\
\text { al (2003) }\end{array}$ \\
\hline 8. & Saponin dan steroid & Caspase , Bax, Bcl 2 & $\begin{array}{l}\text { Menginduksi apoptosis sel HT29 dan HCT } 116 \text { melalui } \\
\text { penurunan regulasi Bcl } 2 \text { dan mempengaruhi protein } \\
\text { caspase } 9\end{array}$ & $\begin{array}{l}\text { Yao M et } \\
\text { al (2020) }\end{array}$ \\
\hline
\end{tabular}

Penelitian dengan mekanisme aksi yang diperantarai oleh protein BCL2 dan Bax dilakukan oleh dua peneliti Basu \& Maier 2018, senyawa aktif yang berperan dalam penelitian adalah Seskuiterpenoid. Protein yang digunakan dalam benelitian yaitu BCL 2 dan Bax selanjutnya mekanisme aksi yang berperan berupa menginduksi jalur apotosis dengan meningkatkan level ekspresi protein Bax, dan menghambat protein Bcl-2. Yao M et al 2020, senyawa aktif yang berperan dalam penelitian adalah Saponin dan steroid. Selanjutnya protein yang berperan dalam penelitian yaitu Caspase , Bax, Bcl 2 sehingga mempengaruhi mekanisme aksi yaitu Menginduksi apoptosis sel HT29 dan HCT 116 melalui penurunan regulasi Bcl 2 dan mempengaruhi protein caspase 9.

Penelitian dengan mekanisme aksi yang diperantarai oleh protein caspase dilakukan oleh tiga peneliti yaitu Siriwan et al 2011, senyawa aktif yang berperan dalam penelitian adalah seskuiterpen lacton selanjutnya protein yang digunakan dalam penelitian yaitu caspase 3 kemudian mekanisme aksi yang dihasilkan oleh protein caspase 3 dapat menginduksi apoptosis dan menghambat proliferasi sel melalui jalur persinyalan melalui penghambatan NF kB. Basio et al 2015, senyawa aktif yang berperan dalam penelitian adalah seskuiterpen lacton selanjutnya protein yang digunakan dalam penelitian yaitu caspase 3. Kemudian mekanisme aksi yang dihasilkan oleh protein caspase 3 dapat menginduksi apoptosis melalui jalur persinyalan melalui penghambatan NF kB. Smith et al 2016, senyawa aktif yang berperan dalam penelitian adalah Fenolik dan flavonoid selanjutnya protein yang digunakan yaitu Caspase 3 dan cox 2, sehingga mekanisme yang dihasilkan mempengaruhi penginduksi pada proses apoptosis dengan peningkatan aktivitas caspase 3 , dan anti inflamasi pada aktivitas cox 2 .

Penelitian dengan mekanisme aksi yang diperantarai oleh protein cAmp protein kinase dan inhibitor fosfodiesterase dilakukan oleh satu peneliti yaitu Senyawa aktif yang berperan dalam penelitian adalah Flavon dan Flavanon. Selanjutnya protein yang berperan dalam mekanisme aksi yaitu cAmp protein kinase dan inhibitor fosfodiesterase sehingga mempengaruhi Mempengaruhi proliferasi seluler dan viabilitas pada sel HT29 (cancer colon).

Berdasarkan uraian diatas mengenai mekanisme aksi yang berpengaruh apoptosis pada sel kanker Xu R et al 2013, senyawa aktif yang berperan dalam penelitian adalah flavonoid dengan adanya senyawa tersebut mekanime aksi 
yang dihasilkan terhadap penelitian mempengaruhi penghambatan proliferasi sel dan tranformasi sel karsinogenik, senyawa flavonoid mampu menginduksi apoptosis sel PC-3. Pec M et al 2003, senyawa aktif yang berperan dalam penelitian adalah Terpenoid dehydrothyrsiferol selanjutnya mekanisme aksi yang mempengaruhi dalam penelitian ini berupa berpengaruhi pada jalur apoptosis terhadap siklus sel pada fase G1, fase $\mathrm{S}$, dan fase G2 / M.

\section{KESIMPULAN}

Pertama, berdasarkan kajian literatur tanaman bunga matahari kultur sel yang berperan pada tanaman bunga matahari (Helianthus annus L) Sel A549 (sel kanker paru), sel Caco -2 (sel kanker kolorektal), sl (RD) Rhabddomysarcoma (Sel kanker otot rangka), sel A375 sel (melanoma) sel MDA -AMB 231, sel HCT 116 (sel kolorectal) sel T98G (sel otak dan sumsum tulang belakang) sel Hela (kanker servic), Neuroblastoma.

Kedua, kandungan senyawa aktif yang diduga memiliki aktivitas antikanker pada tanaman bunga matahari (Helianthus annus L) adalah 5-pentildihidrofuran-2(3H)-satu, (Z)metil 4-(isobutiriloksi) but-3-enoat, dan asam 2fenilasetat, Flavonid, asam palimitat, asam linolenat, asam -Linoleat dan asam Stearidonic, Terpenoid, sesquiterpen dan steroid, asam palimitat, asam linolenat, asam -Linoleat dan asam Stearidonic, terpinene, terpinolene dan linalool alkaloid, glikosida, flavonid dan terpenoid, saponin, flavonoid dan tanin, steroid dan sesquiterpen, saponin, flavonoid dan tanin, flavonoid, sesquiterpen dan lakton dan Lektin.

Ketiga, mekanisme aksi senyawa aktif pada tanaman bunga matahari (Helianthus annus L) Menghambat apoptosis, induksi metastasis, proliferasi sel, transformasi sel, invasi, metastasis, viabilitas sel, mempengaruhi jalur apoptosis terhadap siklus sel pada fase G1, fase $\mathrm{S}$, dan fase G2 / M.

\section{UCAPAN TERIMAKASIH}

Terimakasih penulis ucapakan kepada fakultas S2 Farmasi universitas setia budi yang sudah memfasilitasi penelitian kajian literatur ini sehingga penelitian sudah selesai.

\section{DAFTAR PUSTAKA}

Agulloa et al. 1996. Comparative effects of flavonoids on the growth, viability and metabolism of a colonic adenocarcinoma cell line (HT29 cells). Cancer letter 105 : 61 -70 .

Amirulloh M.F. 2018. Uji Aktivitas Ekstrak Etanol 96\% Daun Bunga Matahari (Helianthus Annus L) Terhadap Apotosis , Siklus Sel, Dan Ekspresi P53 Pada Sel Kanker Serviks Hela. Univesitas islam negeri maulana malik ibrahim malang. Fakultas kedokteran dan ilmu kesehatan.

Basio et al. 2015. Cytotoxic and apoptotic effects of leptocarpin, a plant-derived sesquiterpene lactone, on human cancer cell lines. Chemico-Biological Interactions. 415- 421. 242

Basu \& Maier. 2018. Phytoestrogens and breast cancer: In vitro anticancer activities of isoflavones, lignans, coumestans, stilbenes and their analogs and derivatives. Biomedicine and Pharmacotherapy. 107:1648- 1666.

Haryanti S \& Widyastuti Y. 2017. Aktivitas Sitotoksik Pada Sel MCF-7 dari Tumbuhan Indonesia untuk Pengobatan Tradisional Kanker Payudara. Media Litbangkes 27(4) :247 - 254

Kementrian Kesehatan Republik Indonesia, 2014. Profil Kesehatan Indonesia 2014, http://www.depkes.go.id/folder/view/01/str ucture-publikasi-data-pusat-data-daninformasi.html.

KH-Al Jumaily $\mathrm{R}$ et al. 2013. Anticancer Activity of Sunflower (Helianthus annuns L.) Seeds oil against cell lines. Iraqi journal of science 1003 - 1009 .

Nasarudin. 2013. Potensi Sitotoksik Ekstrak Batang Bunga Matahari (Helianthus Annuus L.) Terhadap Sel Kanker Kolon Hct 116. Institut pertanian bogor. Departemen 
Biokimia Fakultas Matematika Dan Ilmu Pengetahuan Alam

Orsomando. 2016. Mexican sunflower (Tithonia diversifolia, Asteraceae) volatile oil as a selective inhibitor of Staphylococcus aureus nicotinate mononucleotide adenylyltransferase (NadD). Industrial Crops and Products 85:181-189

Pec M, et al. 2003. Induction of apoptosis in estrogen dependent and independent breast cancer cells by the marine terpenoid dehydrothyrsiferol. Pharmacology 65:1451-1461.

Pinedo, et al. 2017. Anti-neuroblastoma properties of a recombinant sunflower lectin. International Journal of Molecular Sciences 18:92

Shupaphon \& predanon. 2019. Evaluation of in vitro alpha-glucosidase inhibitory, antimicrobial,and cytotoxic activities of secondary metabolites from the endophytic fungus, Nigrospora sphaerica, isolated from Helianthus annuus. Annals of Microbiology 69:1397-1406.

Siriawan et al. 2011. Effect of epoxides and $\alpha$ methylene- $\gamma$-lactone skeleton of sesquiterpenes from yacon (Smallanthus sonchifolius) leaves on caspase-dependent apoptosis and NF- $\mathrm{KB}$ inhibition in human cercival cancer cells. Fitoterapia 82(7):1093-1101

Smith et al. 2016.Chemopreventive potential of sunflower seeds in a human colon cancer cell line. International Journal of Cancer Research 12:40-50.

Syifa et al. 2013. Pesona Eksotika Batang Bunga Matahari (Helianthus Annuus L.) Sebagai Antikanker Kolon Dan Uji Sitotoksik. Institut Pertanian Bogor Bogor.

WHO. 2016. Cancer. Diakses pada Oktober 2019,http;//www.who.int/mediacentre/facts heets/fs297/en//.

$\mathrm{Xu} \mathrm{R}$ et al. 2013. Inhibition effects and induction of apoptosis of flavonoids on the prostate cancer cell line PC-3 in vitro. Food Chemistry 138(1):48-53

Yao M et al. 2020. PP9, a steroidal saponin, induces $\mathrm{G} 2 / \mathrm{M}$ arrest and apoptosis in human colorectal cancer cells by inhibiting the PI3K/Akt/GSK3 $\beta$ pathway. ChemicoBiological Interactions 331. 